\title{
Application and Impact of New Technologies in the Supply Chain Management During COVID-19 Pandemic: A Systematic Literature Review
}

\author{
Submitted 20/03/21, $1^{\text {st }}$ revision 12/04/21, $2^{\text {nd }}$ revision 29/04/21, accepted 20/05/21
}

\author{
Muhammad Rahies Khan ${ }^{1}$, Amir Manzoor ${ }^{2}$
}

\begin{abstract}
:
Purpose: The purpose of this study is to examine the application of emerging technologies during the COVID-19 pandemic and their impact on supply chain management.

Design/Methodology/approach: A systematic literature review was conducted to identify the application and impact of new technologies on supply chain management.

Findings: The findings revealed that blockchain technology, IoT, artificial intelligence, big data analytics, cloud computing, 5G and smartphone application, and the use of robots and drones are the key technologies used during COVID-19 in supply chain management, and they showed a substantial impact on the supply chain resilience, agility, and adaptability. Key barriers include higher investment costs, lack of government regulations and support, and deficiency of skilled and technical human resources faced during these technologies' implementation.

Practical Implications: This study evaluated the systematic review through the google scholar search engine and only adopted peer-reviewed scholarly journals, conference proceedings, and opinion papers. The study provides valuable insight to supply chain officials, policymakers, and governments. The emerging technologies have the crucial potential to resolve the supply chain disruptions, if they are addressed seriously.

Originality/value: This study provides social implications by providing insight regarding the improved standards of living. This study is the first to address emerging technologies in supply chain management during COVID-19.
\end{abstract}

Keywords: Supply chain, industry 4.0, blockchain, application, impact, IoT.

Paper type: Literature review.

${ }^{1}$ Ph.D., Scholar Department of Management Sciences Bahria University Karachi, Pakistan, mrahies581@gmail.com;

${ }^{2}$ Associate Professor Department of Management Sciences Bahria University Karachi, Pakistan, amirmanzoor.bukc@bahria.edu.pk; 


\section{Introduction}

The twenty-first century brings dramatic changes and challenges in the global market for every sector. Due to uncertain reasons, the disruptions and disturbances have brought the world into a state of utter many times in history. Significantly, the change in international policies, oil price crises, and financial crises of 2008 has shaken every area of life (Papadopoulos et al., 2020). Similarly, the outbreaks of certain epidemics and pandemics have almost shut the world down completely. The severe natural disruptions were the Swine flu, Ebola virus, MERS, SARS, and SARS CoV2/COVID-19. These disruptions have challenged traditional thinking and way of doing things. All these natural disruptions impacted the world worse, but the COVID19 pandemic differently and fiercely affected international businesses. The reason is evident that globalization and technological innovations have made things complicated, interlinked, and interdependent. Distribution of businesses across the world to get competitive and locational advantages is the strategy of present businessmen. To facilitate and fulfill the raw material, finished goods, and intermediate products requirements of these segregated businesses, the supply chain played a key role. Due to the COVID-19 pandemic, the borders and even local movement have been made restricted as an initial strategy to cope with the further spread of this deadly virus. The first measure was the travel ban of humanitarian logistics, which stopped the movements of international supply.

This restricted supply of goods was initially evident in China, where the world's largest firms, like General Electric, Volkswagen, Nike, Airbus, and Toyota, with manufacturing plants at Wuhan city, have stopped their operations. The effects of SARS CoV2 on supply chains and other business operations have already been addressed by different authors and academicians (Choi, 2020; Govindan et al., 2020; Ivanov, 2020a; Lin et al., 2020; Sarkis et al., 2020; Grima et al., 2020). The SARS CoV2 significantly affects the entire business community and affects the efficient operations and supply chain business models. According to Lin et al. (2020), COVID19 has already severely affected operations and supply chain management. Among fortune 1000 companies, supply chains of $94 \%$ are disrupted by the COVID-19 pandemic (Fortune, 2020). The studies of Ivanov (2020) and Pavlov et al. (2019) revealed that these disruptions had ripple effects. Many companies worldwide, including automobiles, electronics, medical equipment, and consumer goods, face severe disruptions that also experience ripple effects (Dolgui et al., 2018; Ivanov, 2020b). China is considered the world's production hub, the COVID-19 pandemic disruption initially started there and covered the world. The ripple effect requires adequate strategies and actions to minimize these effects, including robust supply chain resilience strategies (Chen et al., 2019; Ivanov and Sokolov, 2019). The supply chain disruption can be responded through digitalization and by promoting flexible operations and supply chain management (Ivanov, 2019).

It is evident from the supply chain management literature that different authors have investigated the different epidemics for different purposes. For example, an outbreak of Ebola, influenza Cholera, and malaria has been discussed by Buyuktahtakm 
(2018), Mamani et al. (2013), Anparasan and Lejeune (2017), and Parvin et al. (2018), respectively. Most of these studies have paid particular attention to allocating resources, procurement and distribution policies, and quick health care responses. Despite this, recent supply chain literature has also made a profound contribution towards supply chain response and operations in response to epidemic outbreak (Aldrighetti et al., 2019; Paul and Venkateswaran, 2020), but the role of technology and innovation in supply chain resilience and operations management has not been adequately investigated.

The literature revealed that digital technology's adoption as a strategic tool could enhance business performance, production capabilities, effectiveness, and resilience (Bruque and Moyano, 2007; Chan et al., 2019; Dibrell et al., 2008; Kleis et al., 2012). The supply chain faces crises at different times, and these events compel the organizations to adopt adequate measures to combat these crises. Use of digital and emerging technologies such as mobile and associated technologies, internet like $3 \mathrm{G} / 4 \mathrm{G}$ and now $5 \mathrm{G}$, business analytics, use of artificial intelligence, industry 4.0, and social media add value creation and provide organizations a competitive advantage in their business operations. However, there is still insufficient literature regarding the use, adoption, and incorporation of these information technology tools in supply chain operations, especially in supply chain resilience. This paper discuss the application and impact of new technologies used by the organizations to combat the situation created by the COVID-19 pandemic through a comprehensive literature review from December 2019- December 2020. In this regard, the following research questions and research objectives were formulated.

- RQ1: What are the new technologies used in supply chain management during the COVID-19 pandemic period?

- RQ2: How these emerging technologies impact supply chain resilience and operations?

Based on these research questions following research objectives were formulated.

- To identify the new emerging technologies used during the period of the COVID-19 pandemic.

- To identify the sectors/areas where these emerging technologies have provided efficient value for the supply chain management.

- To identify the impact of these new emerging technologies in supply chain management.

- To identify the barriers in implementing the emerging technologies in supply chain management.

The rest of the paper is designed as section 2 discussed the methodology and inclusion/exclusion criteria. Section three will address the application and impact of emerging technologies in the supply chain during intense disruption due to the COVID-19 pandemic. We then outline potential research avenues and reflect on the 
managerial implications of using new technologies in supply chain resilience to combat the situation caused by the COVID-19 pandemic. The last section of the paper presented the conclusions.

\section{Research Methodology}

\subsection{Initial Selection Criteria of Selected Articles}

For the initial search, the google scholar database was used and identified 78 articles using a custom search option, i.e., from 2019-2020. The articles of 2019 are then identified based on month, i.e., December 2019 and later. The initial search was done by using keywords like "emerging technologies," "New technologies," "supply chain," and "COVID-19". In the second phase, each technology was separately searched with keywords like "blockchain," "artificial intelligence," "IoT," "cloud computing," "smartphone technology," "5G technology," "supply chain," and "COVID-19" respectively. Google Scholar was searched for up to 20 pages for general technology search, and independent technologies search separately. To maintain quality control, as described by David and Han (2004), only the published peer-reviewed scientific and impact factor journal along with conference proceedings and opinion papers are selected. Hence, the books, book sections, and trade journals were excluded.

\subsection{Content Screening and Complementary Search}

For content screening, a broad definition of supply chain management, new emerging technologies, and independent technologies like AI, IoT, cloud computing, blockchain smartphone technologies, and $5 \mathrm{G}$ technologies were selected to identify and include the relevant articles. For inclusion criteria, we had gone through the keywords, title, and abstract of the articles. Moreover, the main body of the text was also critically observed during inclusion. Articles that reported the use of emerging technologies in supply chain management during COVID-19 were selected. On the other hand, articles that did not correctly define the use of technologies in the supply chain and mentioned the use of new technologies in other fields besides the supply chain were excluded. The initial literature search was done in September 2020. In December 2020, an additional search was also made using the same method. Through this criterion, we successfully obtained 28 articles for final review. The finalized articles are shown in Table 1.

\section{Discussion}

\subsection{RO1 Application of Emerging Technologies in Supply Chain Management}

The spread of the COVID-19 pandemic severely disrupted the supply chains across the world, and disruptions are the happenings that interfere with the normal flow of raw material, finished goods, and services in a system (Blackhurst et al., 2011). These extreme levels of disruption in the free flow of goods and services severely and 
negatively impact the growth of business and supply chain efficiency (Papadopoulos et al., 2017). Hence, to cope with such types of disruptions and interferences, new digital technologies are exponentially used across the world in global supply chains.

Table 1. Finalized articles

\begin{tabular}{|c|c|c|c|c|c|c|c|}
\hline Topic & E & $\frac{\frac{1}{2}}{\frac{2}{2}}$ & 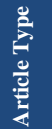 & 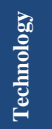 & 苞 & $\begin{array}{l}\text { Application in the supply chain during } \\
\text { COVID-19 Pandemic }\end{array}$ & Impact / Findings \\
\hline $\begin{array}{l}\text { Redesigning Supply } \\
\text { chains using } \\
\text { Blockchain- } \\
\text { Enabled Circular } \\
\text { Economy and } \\
\text { COVID-19 } \\
\text { Experiences }\end{array}$ & 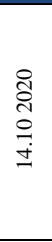 & 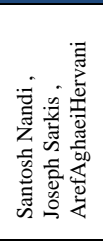 & 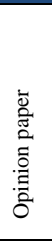 & 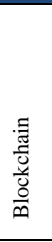 & 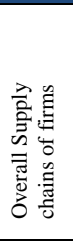 & $\begin{array}{l}\text { Provide insights from the COVID-19 } \\
\text { pandemic for making supply chains more } \\
\text { resilient, transparent, and sustainable. } \\
\text { These insights include supply chains } \\
\text { needing to develop localization, agility, } \\
\text { and digitization (LAD) characteristics. } \\
\text { They linked LAD to a potential solution } \\
\text { using blockchain technology and circular } \\
\text { economy principle capabilities. }\end{array}$ & $\begin{array}{l}\text { Localization, agility, and digitalization of } \\
\text { products enhance the supply chain } \\
\text { agility, resilience, and adaptability. }\end{array}$ \\
\hline $\begin{array}{l}\text { Improvement of } \\
\text { public distribution } \\
\text { system efficiency } \\
\text { applying blockchain } \\
\text { technology } \\
\text { duringthe pandemic } \\
\text { outbreak (COVID- } \\
\text { 19) }\end{array}$ & @્ & 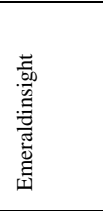 & 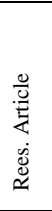 & 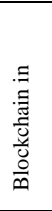 & 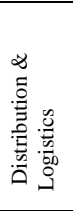 & $\begin{array}{l}\text { To analytically examine the usage of } \\
\text { blockchain technology in public } \\
\text { distribution system SC to overcome the } \\
\text { issues of ghost demands, shrinkage, and } \\
\text { misplacement }\end{array}$ & $\begin{array}{l}\text { The results show that the adoption of BT } \\
\text { in a charitable supply chain can reduce } \\
\text { pilferage and ghost demand significantly }\end{array}$ \\
\hline $\begin{array}{l}\text { Does digitalizing } \\
\text { the supply chain } \\
\text { contribute to its } \\
\text { resilience }\end{array}$ & $\begin{array}{l}\text { तิ } \\
\text { ลั } \\
\text { ลू }\end{array}$ & 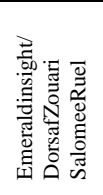 & 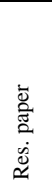 & 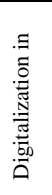 & 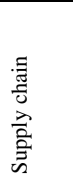 & $\begin{array}{l}\text { The purpose of this paper is to investigate } \\
\text { the link between SCR and SC } \\
\text { digitalization. }\end{array}$ & $\begin{array}{l}\text { Digitalization of supply chains has } \\
\text { increased supply chain resilience. }\end{array}$ \\
\hline $\begin{array}{l}\text { Artificial } \\
\text { Intelligence in the } \\
\text { Agri-Food System: } \\
\text { Rethinking } \\
\text { Sustainable } \\
\text { Business Models in } \\
\text { the COVID-19 } \\
\text { Scenario } \\
\end{array}$ & 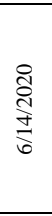 & 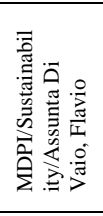 & 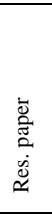 & 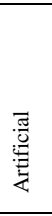 & 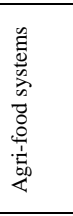 & $\begin{array}{l}\text { To investigate the artificial intelligence } \\
\text { (AI) function in the agri-food industry, as } \\
\text { well as the role of stakeholders in its } \\
\text { supply chain }\end{array}$ & $\begin{array}{l}\text { The findings highlight interesting issues } \\
\text { about AI towards a "space economy" to } \\
\text { achieve sustainable and responsible } \\
\text { business models, also in the perspective } \\
\text { of the COVID-19 pandemic scenario. }\end{array}$ \\
\hline $\begin{array}{l}\text { Artificial } \\
\text { Intelligence in } \\
\text { Supply Chain } \\
\text { Operations } \\
\text { Planning: } \\
\text { Collaboration and } \\
\text { Digital Perspectives }\end{array}$ & $\begin{array}{l}\text { ڤิ } \\
\text { ลิ } \\
\text { ลू }\end{array}$ & 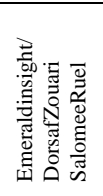 & 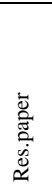 & 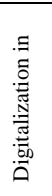 & $\begin{array}{l}\text { ज्ञ } \\
\text { तू } \\
\text { ते } \\
\text { 产 }\end{array}$ & $\begin{array}{l}\text { To investigate the link between SCR and } \\
\text { SC digitalization }\end{array}$ & $\begin{array}{l}\text { Results show that hybridization man- } \\
\text { machine and collaboration and ethical } \\
\text { aspects are understudied. }\end{array}$ \\
\hline $\begin{array}{l}\text { The potential of } \\
\text { remote sensing and } \\
\text { artificial } \\
\text { intelligence as tools } \\
\text { to improve the } \\
\text { resilience of } \\
\text { agriculture } \\
\text { production systems } \\
\end{array}$ & $\begin{array}{l}\text { ลิ } \\
\text { ปั } \\
\text { ปั }\end{array}$ & 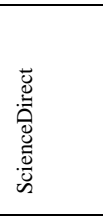 & 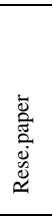 & 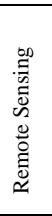 & & $\begin{array}{l}\text { This review focuses on the use of recent } \\
\text { technological advances in remote sensing } \\
\text { and AI to improve the resilience of } \\
\text { agricultural systems }\end{array}$ & $\begin{array}{l}\text { This review focuses on the use of recent } \\
\text { technological advances in remote sensing } \\
\text { and AI to improve the resilience of } \\
\text { agricultural systems, }\end{array}$ \\
\hline $\begin{array}{l}\text { A digital supply } \\
\text { chain twin for } \\
\text { managing the } \\
\text { disruption risks and } \\
\text { resilience in the era } \\
\text { of } \\
\text { Industry } 4.0\end{array}$ & 岕 & 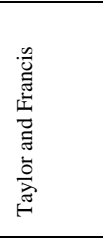 & 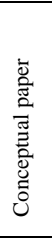 & 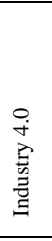 & 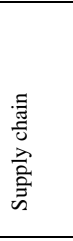 & $\begin{array}{l}\text { Theytheorize a notion of a digital supply } \\
\text { chain (SC) twin-a computerized model } \\
\text { that represents network states for any } \\
\text { given moment in real-time. They explore } \\
\text { the conditions surrounding the design and } \\
\text { implementation of the digital twins when } \\
\text { managing disruption risks in SCs. }\end{array}$ & $\begin{array}{l}\text { The results of this study contribute to the } \\
\text { research and practice of SC risk } \\
\text { management by enhancing predictive and } \\
\text { reactive decisions to utilize the } \\
\text { advantages of SC visualization, historical } \\
\text { disruption data analysis, and real-time } \\
\text { disruption data and ensure end-to-end } \\
\text { visibility and business continuity in } \\
\text { global companies }\end{array}$ \\
\hline
\end{tabular}




\begin{tabular}{|c|c|c|c|c|c|c|c|}
\hline $\begin{array}{l}\text { Crashed! Why } \\
\text { Drone Delivery Is } \\
\text { Another Tech Idea } \\
\text { not Ready to Take } \\
\text { Off }\end{array}$ & 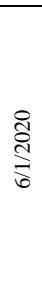 & 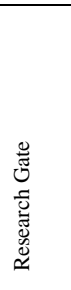 & 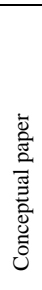 & 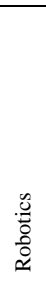 & 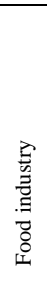 & $\begin{array}{l}\text { To examine why drone delivery is another } \\
\text { tech idea not ready to take off }\end{array}$ & $\begin{array}{l}\text { Factors that were hindering consumers' } \\
\text { behavioral intentions to use drone food } \\
\text { delivery services were consumers' } \\
\text { unfamiliarity and negative perceptions } \\
\text { toward drone delivery in that it is } \\
\text { unregulated, dangerous, risky, lack of } \\
\text { quantified risk assessments, intimidating, } \\
\text { related to military and defense, and } \\
\text { lengthy in the process to obtain } \\
\text { authority's permission to operate food } \\
\text { delivery services by drones }\end{array}$ \\
\hline $\begin{array}{l}\text { A Comprehensive } \\
\text { Review of the } \\
\text { COVID-19 } \\
\text { Pandemic and the } \\
\text { Role of IoT, Drones, } \\
\text { AI, Blockchain, and } \\
\text { 5G in } \\
\text { Managing } \\
\text { Impact }\end{array}$ & 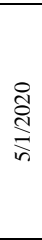 & 空 & 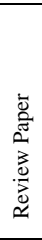 & 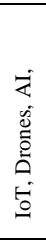 & & $\begin{array}{l}\text { This study highlights its impact on the } \\
\text { global economy. In drawing things to a } \\
\text { close, we explore the use of technologies } \\
\text { such as the Internet of Things (IoT), } \\
\text { Unmanned Aerial } \\
\text { Vehicles (UAVs), blockchain, Articial } \\
\text { Intelligence (AI), and 5G, among others, } \\
\text { to help mitigate the impact of COVID-19 } \\
\text { outbreak. }\end{array}$ & $\begin{array}{l}\text { The study identified the effective use of } \\
\text { industry } 4.0 \text { technologies during the } \\
\text { pandemic to address the delivery of } \\
\text { medical equipment in medical sciences. }\end{array}$ \\
\hline $\begin{array}{l}\text { A proposed } \\
\text { collaborative } \\
\text { framework by using } \\
\text { artificial } \\
\text { intelligence-internet } \\
\text { of things (AI-IoT) } \\
\text { in COVID-19 } \\
\text { pandemic situation } \\
\text { for healthcare } \\
\text { workers }\end{array}$ & $\underset{\infty}{\stackrel{\Xi}{ٍ ్ ~}}$ & 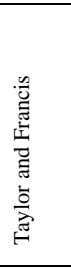 & 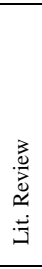 & 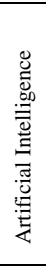 & 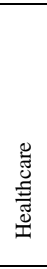 & $\begin{array}{l}\text { To identifythe challenges faced by } \\
\text { healthcare sectors in dealing with this } \\
\text { epidemic outbreak and to propose the } \\
\text { potential solutions in terms of popular } \\
\text { technologies like AI and IoT by doing a } \\
\text { critical analysis of literature }\end{array}$ & $\begin{array}{l}\text { The study provides evidence regarding } \\
\text { the use of industry } 4.0 \text { technologies in } \\
\text { combating the health professionals' } \\
\text { issues. }\end{array}$ \\
\hline $\begin{array}{l}\text { A Review on } \\
\text { Blockchain for } \\
\text { Medical Delivery } \\
\text { Drones in 5G-IoT } \\
\text { Era: Progress and } \\
\text { Challenges }\end{array}$ & 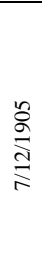 & $\begin{array}{l}\text { 颉 } \\
\text { 至 }\end{array}$ & 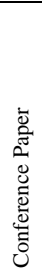 & 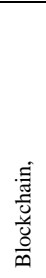 & 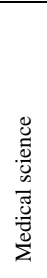 & $\begin{array}{l}\text { Discussedthe importance of blockchain to } \\
\text { improve decentralization, privacy, and } \\
\text { consensusaware medical product delivery } \\
\text { by drones. We firstly review the } \\
\text { background of blockchain, 5G-IoT } \\
\text { ecosystem, and unmanned aerial vehicles } \\
\text { (UAVs). Secondly, we review existing } \\
\text { UAVs capable of performing medial } \\
\text { delivery. }\end{array}$ & $\begin{array}{l}\text { We learn that effective articulation and } \\
\text { augmentation of 5G-IoT aware } \\
\text { architecture shall provide enormous } \\
\text { business opportunities in futuristic } \\
\text { medical delivery drones. }\end{array}$ \\
\hline $\begin{array}{lr}\text { A Review } & \text { on } \\
\text { Drone-Based } & \text { Data } \\
\text { Solutions } & \text { for } \\
\text { Cereal Crops } & \end{array}$ & 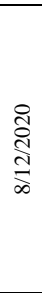 & 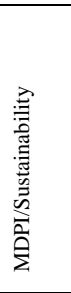 & 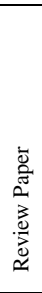 & 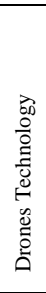 & 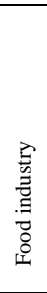 & $\begin{array}{l}\text { To present a deeper understanding of how } \\
\text { the drone-based data solutions can help to } \\
\text { combat food insecurity caused due to the } \\
\text { pandemic, zoonotic diseases, and other } \\
\text { food shocks by enhancing cereal crop } \\
\text { productivity of small-scale farming } \\
\text { systems } \\
\text { low-income countries. }\end{array}$ & $\begin{array}{l}\text { To identify the impact of the COVID-19 } \\
\text { pandemic infood systems and beyond. } \\
\text { Synthesis of the use of drone-based data } \\
\text { solutions and highlight the need to } \\
\text { capitalize on this development towards } \\
\text { improving cereal crop productivity of } \\
\text { small-scale farming systems in low- } \\
\text { income countries. Discussed the } \\
\text { availability of suitable sensors, platform } \\
\text { choices, and the benefits of utilizing } \\
\text { novel machine learning methods. }\end{array}$ \\
\hline $\begin{array}{l}\text { Address business } \\
\text { crisis caused by } \\
\text { COVID-19 } \\
\text { with collaborative } \\
\text { intelligent } \\
\text { manufacturing } \\
\text { technologies }\end{array}$ & 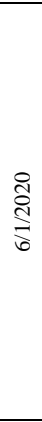 & 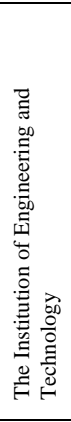 & 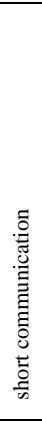 & 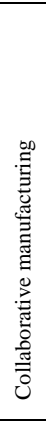 & 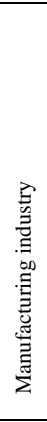 & $\begin{array}{l}\text { This study tries to discuss how } \\
\text { collaborative intelligent manufacturing } \\
\text { technologies can help to address these } \\
\text { challenges through (i) optimal design of } \\
\text { resilient collaborative supplier networks; } \\
\text { (ii) collaborative planning of } \\
\text { manufacturing operations among } \\
\text { geographically distributed manufacturing } \\
\text { plants; (iii) functional redundancy and } \\
\text { dynamic reconfiguration of different shop } \\
\text { floors; (iv) dynamic intelligent } \\
\text { rescheduling of workforces for } \\
\text { factory/shop floor operations; (v) remote } \\
\text { testing and maintenance of manufacturing } \\
\text { equipment with the support of digital } \\
\text { twins technologies. }\end{array}$ & $\begin{array}{l}\text { These methods deeply integrate } \\
\text { emerging ICT, including cloud/edge } \\
\text { computing, IoT, 5G, big data, digital } \\
\text { twins, software agents, to provide } \\
\text { manufacturing enterprises and supply } \\
\text { chains with the ability to quickly respond } \\
\text { to unpredicted disturbing events like the } \\
\text { COVID-19 pandemic and ensure the } \\
\text { resilience and viability of the } \\
\text { manufacturing industry. }\end{array}$ \\
\hline
\end{tabular}




\begin{tabular}{|c|c|c|c|c|c|c|c|}
\hline $\begin{array}{l}\text { An investigation } \\
\text { into emerging } \\
\text { industry } 4.0 \\
\text { technologies as } \\
\text { drivers ofsupply } \\
\text { chain innovation in } \\
\text { Australia }\end{array}$ & 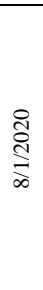 & 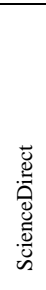 & 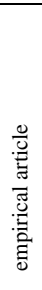 & 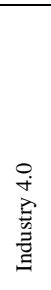 & 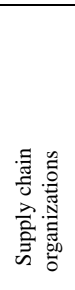 & $\begin{array}{l}\text { To utilize the experience of supplychain } \\
\text { practitioners, to ascertain the current level } \\
\text { of adoption of several key Industry } 4.0 \\
\text { technologies, understand what preparatory } \\
\text { measures are being taken by firms to } \\
\text { ensure they are digitally-readyto utilize } \\
\text { Industry } 4.0 \text { technologies, recognize how } \\
\text { and where these technologies are likely to } \\
\text { impact supply chains, and investigate } \\
\text { whether the organizational size is a factor } \\
\text { in technology adoption }\end{array}$ & $\begin{array}{l}\text { Industry } 4.0 \text { technologies are still in the } \\
\text { infancy stage. The adoption level is } \\
\text { different according to the } \\
\text { sectors. Significant gaps were identified } \\
\text { between expected impact and expected } \\
\text { investment, meaning little spend } \\
\text { iscurrently projected for certain } \\
\text { technologies that are expected to have a } \\
\text { significant impact. }\end{array}$ \\
\hline $\begin{array}{l}\text { Application of } \\
\text { additive } \\
\text { manufacturing in } \\
\text { challenges posed by } \\
\text { COVID-19 }\end{array}$ & $\underset{\infty}{\stackrel{\overbrace{}}{ٍ ٍ ~}}$ & 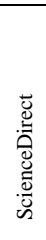 & 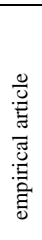 & $\stackrel{\geqq}{:}$ & 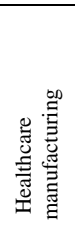 & $\begin{array}{l}\text { Discussed how additive manufacturing } \\
\text { has played a role in this time of crisis. } \\
\text { There has been increased adoption of } \\
\text { additive manufacturing to overcome the } \\
\text { demand created by this pandemic. }\end{array}$ & $\begin{array}{l}\text { The application of Additive } \\
\text { Manufacturing has been in ventilators, } \\
\text { splitter multiplying ventilator capacity, } \\
\text { face shield, swabs for testing, 3-D } \\
\text { bioprinting, antimicrobial polymers, non- } \\
\text { invasive positive end-expiratory pressure } \\
\text { (PEEP) masks, oxygen valves, lung } \\
\text { models, etc. helped in the fight against } \\
\text { COVID- } 19\end{array}$ \\
\hline $\begin{array}{l}\text { Application of } \\
\text { Blockchain } \\
\text { Technology in } \\
\text { Optimizing E-tailer } \\
\text { Supply Chain Costs: } \\
\text { Public and } \\
\text { Consortium } \\
\text { Blockchains }\end{array}$ & 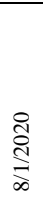 & 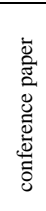 & & 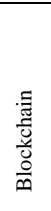 & 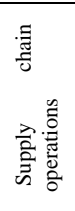 & $\begin{array}{l}\text { Investigate the cost determinants of public } \\
\text { and consortium blockchains in an } \\
\text { operational framework of the e-tailer } \\
\text { supply chain. }\end{array}$ & $\begin{array}{l}\text { The findings emphasize that the } \\
\text { transaction fee is a determining factor, } \\
\text { and the public blockchain operations are } \\
\text { costly in long term operations than the } \\
\text { consortium blockchain operations }\end{array}$ \\
\hline $\begin{array}{lr}\text { Applications } & \text { of } \\
\text { industry } 4.0 & \text { to } \\
\text { overcome } & \text { the } \\
\text { COVID-19 } & \\
\text { operational } & \\
\text { challenges } & \end{array}$ & 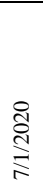 & 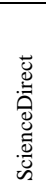 & 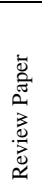 & $\begin{array}{l}\stackrel{0}{+} \\
\stackrel{B}{E} \\
\stackrel{0}{\Xi} \\
\stackrel{\Xi}{E}\end{array}$ & 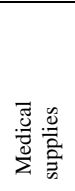 & $\begin{array}{l}\text { To identify the operational challenges } \\
\text { faced by retailers in providing efficient } \\
\text { services. The study also aimed to propose } \\
\text { the roadmap of Industry } 4.0 \text { to reduce the } \\
\text { impact of COVID-19. }\end{array}$ & $\begin{array}{l}\text { Identified twelve significant challenges } \\
\text { for the retail sectors that are acting as } \\
\text { operational barriers and provided the } \\
\text { application of Industry } 4.0 \text { technologies } \\
\text { to deal with it. }\end{array}$ \\
\hline $\begin{array}{l}\text { Artificial } \\
\text { Intelligence in the } \\
\text { Agri-Food System: } \\
\text { Rethinking } \\
\text { Sustainable } \\
\text { Business Models in } \\
\text { the } \\
\text { COVID-19 } \\
\text { Scenario }\end{array}$ & 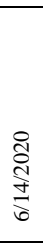 & 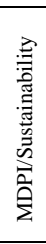 & 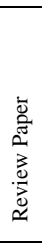 & 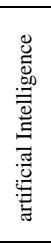 & $\frac{3}{8}$ & $\begin{array}{l}\text { To investigate the artificial intelligence } \\
\text { (AI) functions in the agri-food industry, as } \\
\text { well as the role of stakeholders in its } \\
\text { supply chain. }\end{array}$ & $\begin{array}{l}\text { The findings highlight the use of AI } \\
\text { towards a "space economy" to achieve } \\
\text { sustainable and responsible business } \\
\text { models, also in the perspective of the } \\
\text { COVID-19 pandemic scenario }\end{array}$ \\
\hline $\begin{array}{l}\text { Artificial } \\
\text { intelligence in } \\
\text { supply chain } \\
\text { management: A } \\
\text { systematic literature } \\
\text { review }\end{array}$ & 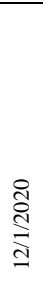 & 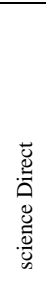 & 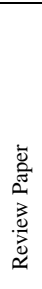 & 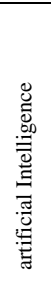 & 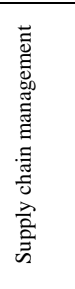 & $\begin{array}{l}\text { To identify the contributions of artificial } \\
\text { intelligence (AI) to supply chain } \\
\text { management (SCM) through a systematic } \\
\text { review of the existing literature. To } \\
\text { address the current scientific gap of AI in } \\
\text { SCM, this study aimed to determine the } \\
\text { current and potential AI techniques that } \\
\text { can enhance both the study and practice of } \\
\text { SCM. }\end{array}$ & $\begin{array}{l}\text { Our results indicate that the most } \\
\text { prevalent AI technique is ANNs, which } \\
\text { are usually used to find complex patterns } \\
\text { that humans cannot find. ANNs can be } \\
\text { applied to approximation, optimization, } \\
\text { clustering, function, and prediction, } \\
\text { retrieval by content, and process control. } \\
\text { Furthermore, we find that the network- } \\
\text { based nature of SCM and logistics } \\
\text { provides a natural framework with which } \\
\text { to implement AI. }\end{array}$ \\
\hline $\begin{array}{l}\text { Big data use and its } \\
\text { outcomes in supply } \\
\text { chain context: the } \\
\text { roles of information } \\
\text { sharing and } \\
\text { technological } \\
\text { innovation }\end{array}$ & 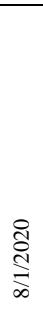 & 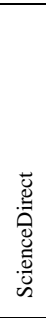 & 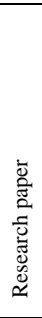 & 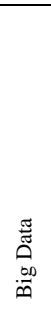 & $\sum_{\infty}^{\infty}$ & $\begin{array}{l}\text { To investigate the use of big data (BDU) } \\
\text { in predicting technological innovation, } \\
\text { supply chain and SMEs' performance and } \\
\text { whether technological innovation } \\
\text { mediates the association between } \\
\text { BDU and firm performance. Additionally, } \\
\text { this research also seeks to explore the } \\
\text { moderating effect of information sharing } \\
\text { in the association between BDU and } \\
\text { technological innovation. }\end{array}$ & $\begin{array}{l}\text { The findings suggest that BDU is } \\
\text { positively related to technological } \\
\text { innovation (product and process) and } \\
\text { organizational outcomes (e.g., supply } \\
\text { chain and SMEs performance). } \\
\text { Technological innovation (i.e., product } \\
\text { and process) significantly mediates the } \\
\text { association between BDU and } \\
\text { organizational outcomes. Moreover, } \\
\text { information sharing positively moderates } \\
\text { the association between BDU and } \\
\text { technological innovations. }\end{array}$ \\
\hline $\begin{array}{l}\text { Blockchain } \\
\text { Technology and Its } \\
\text { Role in Enhancing } \\
\text { Supply Chain } \\
\text { Integration } \\
\text { Capability and } \\
\text { Reducing } \\
\text { Carbon Emission: A } \\
\text { Conceptual } \\
\text { Framework }\end{array}$ & 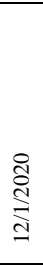 & 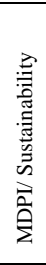 & 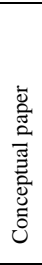 & 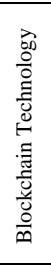 & 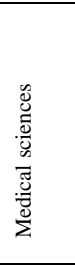 & $\begin{array}{l}\text { Presents a conceptual framework to } \\
\text { understand the role of blockchain in low } \\
\text { carbon supply chain management. }\end{array}$ & $\begin{array}{l}\text { The results indicate that blockchain } \\
\text { technology may be viewed as a strategic } \\
\text { management approach to enhance supply } \\
\text { chain integration and reduce carbon } \\
\text { emissions. }\end{array}$ \\
\hline
\end{tabular}




\begin{tabular}{|c|c|c|c|c|c|c|c|}
\hline $\begin{array}{l}\text { Blockchain } \\
\text { technology } \\
\text { supply in } \\
\text { management: } \\
\text { insights } \\
\text { machine learning } \\
\text { algorithms }\end{array}$ & 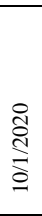 & 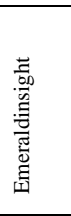 & 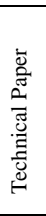 & 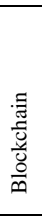 & 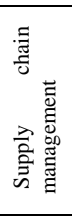 & $\begin{array}{l}\text { To retrieve key components of blockchain } \\
\text { applications in supply chain areas. It } \\
\text { applies natural language processmethods } \\
\text { to generate useful insights from academic } \\
\text { literature. }\end{array}$ & $\begin{array}{l}\text { The research findings are three-fold. } \\
\text { While challenges are of concern, the } \\
\text { focus should be given to the design and } \\
\text { implementation of blockchain in the } \\
\text { supply chain field. Integration with the } \\
\text { internet of things is considered to be of } \\
\text { higher importance. Blockchain plays a } \\
\text { crucial role in food sustainability. }\end{array}$ \\
\hline $\begin{array}{l}\text { Blockchain-- } \\
\text { Internet of things } \\
\text { (IoT) Enabled } \\
\text { Pharmaceutical } \\
\text { Supply Chain for } \\
\text { COVID-19 }\end{array}$ & $\underset{\infty}{\stackrel{\overbrace{}}{ٍ ٍ ~}}$ & 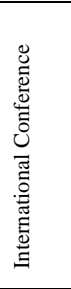 & 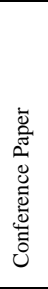 & 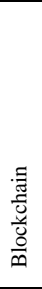 & 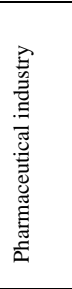 & $\begin{array}{l}\text { To propose the Blockchain-Internet of } \\
\text { things that enabled the pharmaceutical } \\
\text { supply chain through a literature review } \\
\text { process }\end{array}$ & $\begin{array}{l}\text { The developed framework will help in } \\
\text { maintaining trust among stakeholders. It } \\
\text { would improve the visibility, } \\
\text { transparency, and privacy of medical } \\
\text { essentials and data. The adoption of } \\
\text { technologies will reduce the direct } \\
\text { involvement of workers can reduce the } \\
\text { chances of infections. The framework has } \\
\text { several other advantages for the proper } \\
\text { control and management of the COVID- } \\
19 \text {. }\end{array}$ \\
\hline $\begin{array}{l}\text { Digital technology } \\
\text { and Industry } 4.0 \text { for } \\
\text { global value chain } \\
\text { resilience: The case } \\
\text { of COVID-19 and } \\
\text { beyond }\end{array}$ & 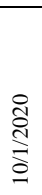 & 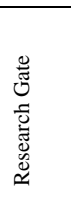 & 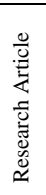 & 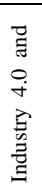 & 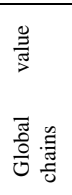 & $\begin{array}{l}\text { How the COVID- } 19 \text { pandemic accelerates } \\
\text { the adoption of digital and industry } 4.0 \\
\text { technologies in global value chains } \\
\text { (GVCs). }\end{array}$ & $\begin{array}{l}\text { As a result, both MNEs and SMEs that } \\
\text { already have access to advanced digital } \\
\text { technologies should determine how best } \\
\text { to implement them throughout their } \\
\text { GVCs. For MNEs and SMEs that do not } \\
\text { yet have access to such technology must } \\
\text { make their acquisition a strategic priority. }\end{array}$ \\
\hline $\begin{array}{l}\text { Do drones have a } \\
\text { real place in a } \\
\text { pandemic fight } \\
\text { for delivering } \\
\text { medical supplies in } \\
\text { healthcare systems } \\
\text { problems? }\end{array}$ & 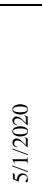 & 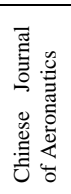 & & 导 & 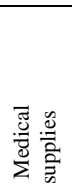 & $\begin{array}{l}\text { Offers a summary of the medical drone } \\
\text { manufacturing, with a specific emphasis } \\
\text { on its approval by the pharmaceutical } \\
\text { sector to solve logistical problems in } \\
\text { healthcare during times of sensitive need. }\end{array}$ & $\begin{array}{l}\text { Drones will be able to optimize the way } \\
\text { of eliminating contamination with a very } \\
\text { high percentage (through the reduction of } \\
\text { human contact) with the increase of the } \\
\text { flexibility of the flight (reaching the less } \\
\text { accessible regions every hour of the day). }\end{array}$ \\
\hline $\begin{array}{l}\text { Identifying Digital } \\
\text { Transformation } \\
\text { Paths in the } \\
\text { Business Model of } \\
\text { SMEs during the } \\
\text { COVID-19 } \\
\text { Pandemic }\end{array}$ & 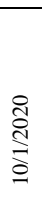 & $\overrightarrow{\mathrm{z}}$ & 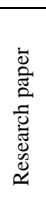 & 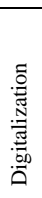 & $\sum_{i=1}^{\infty}$ & $\begin{array}{l}\text { To analyze how small and medium } \\
\text { enterprises (SMEs) cope with } \\
\text { environmental changes due to the } \\
\text { COVID-19 pandemic by pursuing the } \\
\text { business model transformation with the } \\
\text { support of digital technologies }\end{array}$ & $\begin{array}{l}\text { SMEs adopt a different degree of digital } \\
\text { transformations, which can be } \\
\text { summarized into three paths, depending } \\
\text { on the firms' contextual factors. }\end{array}$ \\
\hline $\begin{array}{l}\text { Internet of Things } \\
\text { Based Blockchain } \\
\text { for Temperature } \\
\text { Monitoring and } \\
\text { Counterfeit } \\
\text { Pharmaceutical } \\
\text { Prevention }\end{array}$ & 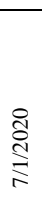 & 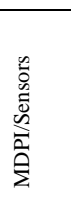 & 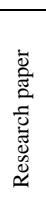 & 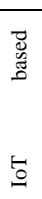 & 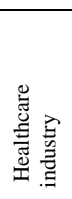 & $\begin{array}{l}\text { An Internet of Things (IoT) sensor-based } \\
\text { blockchain framework is proposed that } \\
\text { tracks and traces drugs as they pass slowly } \\
\text { through the entire supply chain. }\end{array}$ & $\begin{array}{l}\text { On the one hand, these newtechnologies } \\
\text { of blockchain and IoT sensors play an } \\
\text { essential role in supply chain } \\
\text { management }\end{array}$ \\
\hline $\begin{array}{l}\text { IoT in Supply Chain } \\
\text { Management: } \\
\text { Opportunities and } \\
\text { Challenges for } \\
\text { Businesses in Early } \\
\text { Industry 4.0 Context }\end{array}$ & 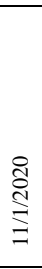 & 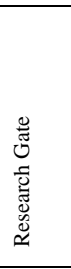 & 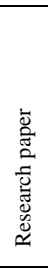 & 乩 & 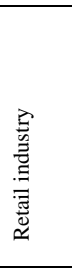 & $\begin{array}{l}\text { Investigates the opportunities and } \\
\text { challenges of IoT use in the supply chains } \\
\text { using grounded theory based interviews } \\
\text { with managers from the Australian retail } \\
\text { industry. }\end{array}$ & $\begin{array}{l}\text { IoT deployment improves visibility of } \\
\text { goods movement, data capture, partner } \\
\text { communication, and business } \\
\text { intelligence. However, retailers face } \\
\text { challenges due to the lack of top } \\
\text { management initiative, new technology } \\
\text { acquisition cost, stakeholders' reluctance } \\
\text { to accept change, unwillingness to share } \\
\text { data, and inadequate interoperability of } \\
\text { software systems }\end{array}$ \\
\hline $\begin{array}{l}\text { Setbacks to IoT } \\
\text { Implementation in } \\
\text { the Function of } \\
\text { FMCG Supply } \\
\text { Chain Sustainability } \\
\text { during } \\
\text { COVID-19 } \\
\text { Pandemic }\end{array}$ & 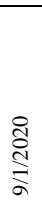 & 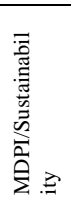 & 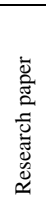 & 啲 & $\sum_{\substack{0\\
}}^{0}$ & $\begin{array}{l}\text { To analyze the setbacks to the } \\
\text { digitalization of business processes and } \\
\text { the sustainability of the FMCG supply } \\
\text { chain based on the implementation of IoT }\end{array}$ & $\begin{array}{l}\text { The results showed significant } \\
\text { differences between business sectors in } \\
\text { terms of the intensity of setbacks to } \\
\text { successful IoT implementation. }\end{array}$ \\
\hline
\end{tabular}

Source: Own creation.

These emerging technologies include artificial intelligence, big data analytics, blockchain, cloud computing, the internet of things, machine learning, smartphone technologies, and 5G technology. All of them are categorized under the industry 4.0 revolution, and the use of these technologies immensely impacts the operations and 
innovations in global supply chains. The use of these technologies across global supply chains enhanced the connectivity and increased the reciprocal trust among the global partners. Due to accuracy in recording transactions, emerging technologies served as a medium of trust among participants (He et al., 2020).

\subsection{RO2 Sectors Where Emerging Technologies Were Implemented}

The extensive use of emerging technologies and business model innovation like ambidexterity, agility, adaptability, and improvisation has never been witnessed in history as used during the COVID-19 period (Dilyard et al., 2020). The wide use of these technologies among all the industries has also been witnessed during this period. The famous industries that adopted the emerging technologies in supply chain operations and business models include the pharmaceutical industry, Agri-food industry, manufacturing, service industry, electronic industry, and construction industry (Dilyard et al., 2020; Manalu et al., 2020; Salah et al., 2020). The adoption and implementation of emerging technologies in these industries provide substantial support to combat the pandemic effects.

Table 2. Sectors Where Emerging Technologies Were Implemented

\begin{tabular}{|c|c|c|c|}
\hline No & Technology Used & Industry & Application \\
\hline 1 & Blockchain & Pharmaceutical & $\begin{array}{l}\text { Blockchain improved the tracing } \\
\text { responsiveness in supply chain resilience. }\end{array}$ \\
\hline 2 & $\begin{array}{l}\text { Artificial } \\
\text { intelligence }\end{array}$ & Agri-food & $\begin{array}{l}\text { Artificial intelligence provides sustainable } \\
\text { business models. }\end{array}$ \\
\hline 3 & $\begin{array}{l}\text { Internet of things } \\
\text { (IoT) }\end{array}$ & Pharmaceutical & $\begin{array}{l}\text { Internet of things enabled tracing and } \\
\text { prediction of future supply chains through } \\
\text { integration. }\end{array}$ \\
\hline 4 & Cloud Computing & Livestock & $\begin{array}{l}\text { Reduces transaction costs and create } \\
\text { metadata for future use. }\end{array}$ \\
\hline 5 & $\begin{array}{l}\text { Smartphone } \\
\text { Technology }\end{array}$ & Manufacturing & Helpful in remotely control the machines \\
\hline 6 & 5G Technology & Manufacturing & $\begin{array}{lll}\text { Successfully } & \text { expedite } & \text { traditiona } \\
\text { transactions. } & & \\
\end{array}$ \\
\hline 7 & $\begin{array}{l}\text { Additive } \\
\text { manufacturing }\end{array}$ & Manufacturing & $\begin{array}{l}\text { Additive manufacturing provides fast pace } \\
\text { manufacturing of medical appliances. }\end{array}$ \\
\hline 8 & $\begin{array}{l}\text { Big data predictive } \\
\text { analytics }\end{array}$ & $\begin{array}{l}\text { Supply chain/ } \\
\text { manufacturing }\end{array}$ & $\begin{array}{l}\text { BDA provides secure, transparent, and } \\
\text { accurate transactions among partners and } \\
\text { increases trust. }\end{array}$ \\
\hline 9 & Drones technology & FMCG & $\begin{array}{l}\text { Export and deliver medical appliances and } \\
\text { other products to remote areas. }\end{array}$ \\
\hline
\end{tabular}

Soucre: Own creation.

\subsection{RO3 Impact of Emerging Technologies on Supply Chain Resilience during COVID-19}

Through a comprehensive literature review, we identified the use of emerging technologies in supply chains during COVID-19 and their impact on supply chain 
resilience and performance. The studies' findings revealed that the use of blockchain technology in public distribution systems reduces the pilferage and ghost demands significantly. Moreover, the shrinkage and misplacement of procured grains can be minimized using RFID technology (Kumar, 2020). Blockchain has decentralized consensus and information sharing characteristics, and they can be used to increase the SC visibility and transactional efficiency, which are more important points to be kept in mind while making decisions during any disruption. Precautionary measures like alternate supply arrangements through negotiating and incentivizing blockchain attributes can be easy to adopt during hard times (Nandi et al., 2021). During the disruption, localization of products, agile production, and digital visibility of required supplies through blockchain technology, adoption can be made (Nandi et al., 2021).

Ray et al. (2020) conducted a study and provide evidence of blockchain use in medical delivery drones in 5 G-IoT periods and find that medical deliveries can be made easy and possible through 5 G-IoT integrated drones. They identify the uses of 5G-IoT integrated drones in reaching disaster-affected areas, looking after patients away from hospitals, helpful in hospital operations, supporting the delivery of blood, sputum, vaccines, surgical appliances, and human organs. Ray et al. (2020). Shen, Yang, and Gao (2020) address the crisis caused due to the COVID-19 pandemic and discusses the role of manufacturing technologies in business. They point out that the company's resilience and survivability during the pandemic need strong collaborations among the supply partners by incorporating the intertwined supply chain networks. They also highlighted IoT and cloud computing's role in enhances transparency and manufacturing procedure by collecting the relevant data from ERP, social networking, and logistics and operation systems.

Similarly, (Hopkins, 2021) investigated the role of industry 4.0 as an innovative tool in the Australian context and finds that the adoption and incorporation of industry 4.0 technologies are at the infancy stage in the country, and larger firms are more ready to adopt and incorporate than the smaller once. Moreover, he mentioned the impact of digital technologies according to different sectors. He discusses the role of long autonomous vehicles in the supply chains and finds strong evidence of lower shipping costs, reduced drivers' daily wages, reduction in accidental events, and reliability.

According to previous literature discussed by Hopkins (2020), big data analytics make the firms capable of correctly forecasting future demands and consumption improve supply chain agility, hence enhancing marketing sales. Similarly, through the internet of things (IoT), firms can enhance the prediction power of supplies by incorporating the sensors in containers, vehicles, and products. On the other hand, blockchain technology usage can improve transparent, secure, and accurate transactions and improve collaboration among supply chain partners.

Moreover, their empirical findings reported that $18 \%$ using artificial intelligence, $12 \%$ report that their organization is already using autonomous vehicles, $44 \%$ of organizations are already users of BDA, only $11 \%$ of organizations are using blockchain technology, 16\% of them already using drones for their supply chains, 
$48 \%$ of them are using IoT technology in practice and $29 \%$ of the responding organizations are using robotic technology. Alongside these emerging technologies' adoption and usage during COVID-19, additive manufacturing also played an essential role in responding to the pandemic. Immediate medical supplies provision by integrating technologies in existing manufacturing and delivery processes has provided a sustainable measure against this pandemic. On this front, Arora (2020) provides evidence of the application and role of additive manufacturing in combating the pandemic. They provide evidence of production and delivery of ventilators, testing swabs, face shields, splitting ventilators for multiple patients, hand sanitizers and their holders, oxygen masks, and non-invasive positive and expiratory pressure masks(PEEP) through additive manufacturing.

COVID-19 pandemic has imposed certain restrictions and challenges to supply chains across the world. The most influential sector damaged by the COVID-19 pandemic is supply chains of different products and services. In this context, Kumar et al. (2020) identified twelve significant operational challenges faced by retailers in providing efficient supplies of medical equipment to the end-users and propose the use of industry 4.0 as a countermeasure to cope up with these challenges. Lack of flexibility, lack of trust, lack of government incentives, communication issues, security concerns in supply chains, imbalance in supply and demand, etc., are the significant challenges he identified in delivering medical equipment during the pandemic. They have provided industry 4.0 like good relationships with supply partners through information sharing, provisions of incentives by governments and cost-sharing, enhanced trust through blockchain and technology integration in systems, and IoT can overcome these challenges, respectively.

\subsection{RO4 Barriers in Implementing the Emerging Technologies}

As the emerging technologies have played a vital role in the fight against the COVID19 different authors also identified 19 pandemic but certain crucial obstacles in the implementation of these emerging technologies. Koncar et al. (2020) identified the potential barriers in implementing industry 4.0 or emerging technologies in supply chain operations. They identified that the higher investment cost, lack of trained workers in implementing and operating the technologies, especially IoT, lack of modern infrastructure to support industry 4.0 are the critical barriers in incorporating these technologies in supply chains. Similarly, the previous studies also reported the same results regarding the acceptance and implementation of emerging technologies in supply chains (Končar et al., 2020; Majeed and Rupasinghe, 2017; Oláh et al., 2020; Rehman et al., 2020; Shahzad et al., 2020). Yadav et al. (2020) also reported the lack of government regulations and lack of trust among the agro-stakeholders as the critical barriers to implementing blockchain technology. Previous literature also supports these findings and evident the organizational and end-users-related challenges and technological and operational challenges as critical barriers to implementing blockchain technology in supply chain management (Wang et al., 2019). 


\section{Practical Implications and Future Research Directions}

Our study has some practical implications for policymakers. Through a comprehensive literature review, we find that emerging technologies serve as the backbone for the sustainability of supply chains and business operations worldwide. Keeping in view the successful implementation of these technologies during the pandemic, we recommend that proper adoption, routinization, and incorporation of industry 4.0 technologies are crucial for the success of supply chain operations in the future. Moreover, we also concluded that firms' competitive advantage has almost been sifted from the traditional resource-based view to the technologically oriented view. Companies need to focus on these emerging technologies critically to get a competitive advantage in the coming era.

Along these, policymakers and governments have to focus on the identified barriers in implementing the emerging technologies in supply chain management. In this context, developing nations need to be more severe and conscious to address the barriers of high investment costs, development of modern infrastructure, and skilled and technical human resources to implement these technologies in their daily operations. Similar to other studies, our study also has some limitations. We have gone through google scholar to get the articles related to emerging technologies in supply chain management. Future studies can be conducted to search for other search engines like Scopus, web of science, and Ebscohost to get more articles related to our topic.

Moreover, we selected published articles and conference papers. Future studies can induct books, book sections, and trade journals in their study to get more insight into the use of emerging technologies in supply chain management during COVID-19. Our review identified that most of the papers had discussed the use of emerging technologies without properly grounding the theoretical background. As theory is the essential part of the research, future research can be conducted to deeply understand these technologies' theoretical and empirical groundings, especially the survivability and resilience of intertwined supply networks. Moreover, the so-far research on digital and emerging technologies is not backed and supported through theoretical grounds. Future research on the use of emerging technologies in the supply chain can be addressed through the theoretical lens to enhance these technologies' understanding and authenticity.

\section{Conclusion}

A comprehensive literature review has been conducted to identify the use of emerging technologies during the COVID-19 pandemic. We have gone through the google scholar database to collect the scholarly published peer-reviewed journals and identify the 78 articles, opinion papers, and conference proceedings from December 2019- December 2020. The literature has provided strong evidence of the successful implementation of emerging technologies in supply chain management in different industries across the world. Further, we identified the different technologies used 
during this pandemic to support the supply chain of products and services. Blockchain technology.Internet of things (IoT). Artificial intelligence (AI), big data analytics (BDA), the use of robotics, drones, UAVs, and 5G technologies are found to be the most prominent technologies used in supply chains during this period. Besides this, we also identified the potential impact of these technologies on the resilience, agility, and performance of supply chain operations. We also provide critical barriers to implementing these emerging technologies. Higher investment costs, technological infrastructure, lack of funds, government incentives and regulations, and insufficient trained and skilled human resources to implement these technologies were the chief barriers. In the end, we provided the practical implications and future research directions.

\section{References:}

Aldrighetti, R., Zennaro, I., Finco, S., Battini, D. 2019. Healthcare supply chain simulation with disruption considerations: A case study from northern Italy. Global Journal of Flexible Systems Management, 20(1), 81-102.

Anparasan, A., Lejeune, M. 2017. Analyzing the response to epidemics: Concept of evidence-based Haddon matrix. Journal of Humanitarian Logistics and Supply Chain Management.

Arora, P.K., Arora, R., Haleem, A., Kumar, H. 2020. Application of additive manufacturing in challenges posed by COVID-19. Materials Today: Proceedings, S2214785320361952. https://doi.org/10.1016/j.matpr.2020.08.323.

Blackhurst, J., Dunn, K.S., Craighead, C.W. 2011. An Empirically Derived Framework of Global Supply Resiliency: Framework of Global Supply Resiliency. Journal of Business Logistics, 32(4), 374-391. https://doi.org/10.1111/j.00000000.2011.01032.x.

Bruque, S., Moyano, J. 2007. Organisational determinants of information technology adoption and implementation in SMEs: The case of family and cooperative firms. Technovation, 27(5), 241-253.

Büyüktahtakın, İ.E., des-Bordes, E., Kıbış, E.Y. 2018. A new epidemics-logistics model: Insights into controlling the Ebola virus disease in West Africa. European Journal of Operational Research, 265(3), 1046-1063.

Chan, C.M., Teoh, S.Y., Yeow, A., Yan, G. 2019. Agility in responding to disruptive digital innovation: Case study of an SME. Information Systems Journal, 29(2), 436-455.

Chen, H.Y., Das, A., Ivanov, D. 2019. Building resilience and managing post-disruption supply chain recovery: Lessons from the information and communication technology industry. International Journal of Information Management, 49, 330342. https://doi.org/10.1016/j.ijinfomgt.2019.06.002.

Choi, T.M. 2020. Innovative "bring-service-near-your-home" operations under Corona-virus (COVID-19/SARS-CoV-2) outbreak: Can logistics become the messiah? Transportation Research Part E: Logistics and Transportation Review, 140, 101961.

David, R.J., Han, S.K. 2004. A systematic assessment of the empirical support for transaction cost economics. Strategic Management Journal, 25(1), 39-58.

Dibrell, C., Davis, P.S., Craig, J. 2008. Fueling innovation through information technology in SMEs. Journal of Small Business Management, 46(2), 203-218.

Dilyard, J., Zhao, S., You, J. 2020. Digital technology and Industry 4.0 for global value chain resilience: The case of COVID-19 and beyond. 
Dolgui, A., Ivanov, D., Sokolov, B. 2018. Ripple effect in the supply chain: An analysis and recent literature. International Journal of Production Research, 56(1-2), 414-430. https://doi.org/10.1080/00207543.2017.1387680.

Fortune. 2020. Coronavirus impact: $94 \%$ of the Fortune 1000 are seeing supply chain disruptions | Fortune. Fortune. https://fortune.com/2020/02/21/fortune-1000coronavirus-china-supply-chain-impact/.

Govindan, K., Mina, H., Alavi, B. 2020. A decision support system for demand management in healthcare supply chains considering the epidemic outbreaks: A case study of coronavirus disease 2019 (COVID-19). Transportation Research Part E:

Logistics and Transportation Review, 138, 101967.

Grima, S., Dalli Gonzi, R., Thalassinos, I.E. 2020. The Impact of COVID-19 on Malta and its Economy and Sustainable Strategies. Available at SSRN: https://ssrn.com/abstract=3644833

He, Q., Meadows, M., Angwin, D., Gomes, E., Child, J. 2020. Strategic Alliance Research in the Era of Digital Transformation: Perspectives on Future Research. British Journal of Management.

Hopkins, J.L. 2021. An investigation into emerging industry 4.0 technologies as drivers of supply chain innovation in Australia. Computers in Industry, 125, 103323. https://doi.org/10.1016/j.compind.2020.103323.

How China can rebuild global supply chain resilience after COVID-19. (n.d.). World Economic Forum. Retrieved from: https://www.weforum.org/agenda/2020/03/coronavirus-and-global-supplychains/.

Ivanov, D. 2019. Disruption tails and revival policies: A simulation analysis of supply chain design and production-ordering systems in the recovery and post-disruption periods. Computers \& Industrial Engineering, 127, 558-570.

Ivanov, D. 2020a. Predicting the impacts of epidemic outbreaks on global supply chains: A simulation-based analysis on the coronavirus outbreak (COVID-19/SARS-CoV2) case. Transportation Research Part E: Logistics and Transportation Review, 136, 101922.

Ivanov, D. 2020b. Viable supply chain model: Integrating agility, resilience and sustainability perspectives-Lessons from and thinking beyond the COVID-19 pandemic. Annals of Operations Research, 1.

Ivanov, D., Sokolov, B. 2019. Simultaneous structural-operational control of supply chain dynamics and resilience. Annals of Operations Research, 283(1), 1191-1210. https://doi.org/10.1007/s10479-019-03231-0.

Kleis, L., Chwelos, P., Ramirez, R.V., Cockburn, I. 2012. Information technology and intangible output: The impact of IT investment on innovation productivity. Information Systems Research, 23(1), 42-59.

Končar, J., Grubor, A., Marić, R., Vučenović, S., Vukmirović, G. 2020. Setbacks to IoT Implementation in the Function of FMCG Supply Chain Sustainability during COVID-19 Pandemic. Sustainability, 12(18), 7391. https://doi.org/10.3390/su12187391.

Končar, J., Vučenović, S.,Marić, R. 2020. Green Supply Chain Management in Retailing Based on Internet of Things. In Integration of Information Flow for Greening Supply Chain Management, 181-202.

Kumar, A. 2020. Improvement of public distribution system efficiency applying blockchain technology during pandemic outbreak (COVID-19). Journal of Humanitarian Logistics and Supply Chain Management, ahead-of-print(ahead-of-print). https://doi.org/10.1108/JHLSCM-06-2020-0050. 
Lin, Q., Zhao, S., Gao, D., Lou, Y., Yang, S., Musa, S.S., Wang, M.H., Cai, Y., Wang, W., Yang, L. 2020. A conceptual model for the outbreak of Coronavirus disease 2019 (COVID-19) in Wuhan, China with individual reaction and governmental action. International Journal of Infectious Diseases.

Majeed, A.A., Rupasinghe, T.D. 2017. Internet of things (IoT) embedded future supply chains for industry 4.0: An assessment from an ERP-based fashion apparel and footwear industry. International Journal of Supply Chain Management, 6(1), 2540.

Mamani, H., Chick, S.E., Simchi-Levi, D. 2013. A game-theoretic model of international influenza vaccination coordination. Management Science, 59(7), 1650-1670.

Manalu, E.P.S., Muditomo, A., Adriana, D., Trisnowati, Y., P, Z.K., H, R.D. 2020. Role Of Information Technology for Successful Responses to Covid-19 Pandemic. 2020 International Conference on Information Management and Technology (ICIMTech), 415-420. https://doi.org/10.1109/ICIMTech50083.2020.9211290.

Nandi, S., Sarkis, J., Hervani, A.A., Helms, M.M. 2021. Redesigning Supply Chains using Blockchain-Enabled Circular Economy and COVID-19 Experiences. Sustainable Production and Consumption, 27, 10-22. https://doi.org/10.1016/j.spc.2020.10.019.

Oláh, J., Aburumman, N., Popp, J., Khan, M.A., Haddad, H., Kitukutha, N. 2020. Impact of Industry 4.0 on Environmental Sustainability. Sustainability, 12(11), 4674.

Papadopoulos, T., Baltas, K.N., Balta, M.E. 2020. The use of digital technologies by small and medium enterprises during COVID-19: Implications for theory and practice. International Journal of Information Management, 55, 102192.

Papadopoulos, T., Gunasekaran, A., Dubey, R., Altay, N., Childe, S.J., Fosso-Wamba, S. 2017. The role of Big Data in explaining disaster resilience in supply chains for sustainability. Journal of Cleaner Production, 142, 1108-1118. https://doi.org/10.1016/j.jclepro.2016.03.059.

Parvin, H., Beygi, S., Helm, J.E., Larson, P.S., Van Oyen, M.P. 2018. Distribution of medication considering information, transshipment, and clustering: Malaria in Malawi. Production and Operations Management, 27(4), 774-797.

Paul, S., Venkateswaran, J. 2020. Designing robust policies under deep uncertainty for mitigating epidemics. Computers \& Industrial Engineering, 140, 106221.

Ray, P.P., Nguyen, K. 2020. A Review on Blockchain for Medical Delivery Drones in 5GIoT Era: Progress and Challenges. 2020 IEEE/CIC International Conference on Communications in China (ICCC Workshops), 29-34. https://doi.org/10.1109/ICCCWorkshops49972.2020.9209931.

Rehman, M.A.U., Ullah, R., Park, C.W., Kim, B.S. 2020. Towards Network Lifetime Enhancement of Resource Constrained IoT Devices in Heterogeneous Wireless Sensor Networks. Sensors, 20(15), 4156.

Salah, K., Jayaraman, R., Ahmad, R., Yaqoob, I., Ellahham, S., Omar, M. 2020. Blockchain and COVID-19 Pandemic: Applications and Challenges.

Sarkis, J., Cohen, M.J., Dewick, P., Schröder, P. 2020. A brave new world: Lessons from the COVID-19 pandemic for transitioning to sustainable supply and production. Resources, Conservation, and Recycling.

Shahzad, A., Zhang, K., Gherbi, A. 2020. Intuitive development to examine collaborative iot supply chain system underlying privacy and security levels and perspective powering through proactive blockchain. Sensors, 20(13), 3760.

Shen, W., Yang, C., Gao, L. 2020. Address business crisis caused by COVID-19 with collaborative intelligent manufacturing technologies. IET Collaborative Intelligent Manufacturing, 2(2), 96-99. https://doi.org/10.1049/iet- 
Application and Impact of New Technologies in the Supply Chain Management

cim.2020.0041.

Wang, Y., Han, J.H., Beynon-Davies, P. 2019. Understanding blockchain technology for future supply chains: A systematic literature review and research agenda. Supply Chain Management: An International Journal.

Yadav, V.S., Singh, A.R., Raut, R.D., Govindarajan, U.H. 2020. Blockchain technology adoption barriers in the Indian agricultural supply chain: An integrated approach. Resources, Conservation and Recycling, 161, 104877. 
